The research program of the Center for Economic Studies (CES) produces a wide range of theoretical and empirical economic analyses that serve to improve the statistical programs of the U.S. Bureau of the Census. Many of these analyses take the form of CES research papers. The papers are intended to make the results of CES research available to economists and other interested parties in order to encourage discussion and obtain suggestions for revision before publication. The papers are unofficial and have not undergone the review accorded official census Bureau publications. The opinions and conclusions expressed in the papers are those of the authors and do not necessarily represent those of the U.S. Bureau of the Census. Republication in whole or part must be cleared with the authors.

POLLUTION ABATEMENT EXPENDITURE BY U.S. MANUFACTURING PLANTS: DO COMMUNITY CHARACTERISTICS MATTER?

by

\author{
Randy A. Becker* \\ U.S. Bureau of the Census
}

CES 03-18 November, 2003

All papers are screened to ensure that they do not disclose confidential information. Persons who wish to obtain a copy of the paper, submit comments about the paper, or obtain general information about the series should contact Sang V. Nguyen, Editor, Discussion Papers, Center for Economic Studies, Washington Plaza II, Room 206, $\overline{\text { Bureau }}$ of the Census, Washington, DC 20233-6300, (301-763-1882) or INTERNET address snguyen@ces.census.gov. 


\title{
Pollution Abatement Expenditure by U.S. Manufacturing Plants: Do Community Characteristics Matter?*
}

\author{
Randy A. Becker \\ Center for Economic Studies \\ U.S. Bureau of the Census
}

November 2003

\begin{abstract}
A number of previous studies have demonstrated the impact of community characteristics on environmental outcomes such as local pollution levels and the siting of noxious facilities. If certain groups are indeed exposed to higher levels of air pollution, it may be due to a greater concentration of air polluters in those communities and/or facilities in those areas investing less in air pollution abatement. This paper examines the latter, using establishment-level data on manufacturing plants from the U.S. Census Bureau's Pollution Abatement Costs and Expenditures (PACE) survey. The empirical formulation herein allows plant-level air pollution abatement operating costs to depend on an array of community characteristics common to this literature. After controlling for establishment characteristics and federal, state, and local regulation, some of these local factors are found to have had an additional effect on air pollution abatement expenditures. In particular, populations with higher homeownership rates and higher per capita income enjoyed greater pollution abatement activity from their nearby plants. Meanwhile, establishments in communities where manufacturing accounted for a greater share of local employment had less pollution abatement spending, suggesting a local constituency that is more resistant to additional regulation. Political ideology is also found to play a role, with plants in areas with larger concentrations of Democrats having more expenditure on air pollution abatement, all else being equal. There is little evidence that race and ethnicity matter when it comes to the pollution abatement behavior of the most pollution-intensive facilities. The findings of this paper support those of a number of recent studies.
\end{abstract}

Keywords: air pollution abatement, community characteristics, manufacturing

JEL codes: L6, Q21, Q25

* This paper has benefited from valuable discussions at the Second World Congress of Environmental and Resource Economists, the 2003 Allied Social Science Association conference, and the Center for Economic Studies. The opinions and conclusions expressed herein are those of the author and do not necessarily represent those of the Bureau of the Census. This paper has been screened to ensure that it does not disclose any confidential information. All errors are my own. 


\section{INTRODUCTION}

There is a growing literature on the ways community characteristics affect local environmental outcomes. Recent studies have shown the importance of various economic and political factors in explaining the level of toxic releases or local ambient pollution (e.g., Kriesel et al. 1996; Arora \& Cason 1999), the siting of polluting facilities (e.g., Hamilton 1993, 1995; Wolverton 2002), local regulatory enforcement (Gray \& Deily 1996), and voting patterns on environment-related ballot initiatives (Kahn \& Matsusaka 1997). Explanatory variables common to many of these studies include household incomes, house values, population density, educational attainment, poverty rate, racial composition, voting behavior, and other measures of local demographics, economic conditions, and political opposition.

In this paper, I examine whether local factors help explain the level of pollution abatement expenditures by manufacturing plants. If certain groups are indeed exposed to higher levels of pollution, as previous studies have suggested, it may be that (a) there are an inordinate number of polluting facilities in those communities and/or (b) facilities in those areas do not invest as much in abatement as they would have otherwise. The latter is the subject of this study.

Here, plant-level air pollution abatement (henceforth, "APA") expenditure per dollar of output is modeled as a function of air quality regulation at the federal, state, and county levels, as well as a number of county characteristics potentially affecting such expenditures, either because facilities behave differently in such areas or because they are regulated more or less stringently in such areas. Establishment-level data on environmental expenditures come from the Census Bureau's Pollution Abatement Costs and Expenditures (PACE) survey, with supplementary data from the Annual Survey of Manufactures (ASM).

Results show that, after controlling for establishment characteristics and various forms of federal, state, and local regulation, some community characteristics have an additional effect, others 
do not. Some of the most noteworthy results are for a subsample of establishments that are particularly high air polluters. In particular, a number of the "political" factors are found to be statistically significant determinants of APA activity. As in some other studies, the percent of homes in an area that are owner-occupied is found to improve local environmental outcomes (in this case, APA investment). Homeowners care about maintaining their properties' value, and may lobby for more stringent regulation than normally required by their state or federal government. Others have argued that a higher proportion of renters implies lower sunk costs and higher mobility by local residents — and therefore less compensation is required in the event of damages.

The proportion of the local population that is engaged in manufacturing or is unemployed has the opposite effect, at least among the most polluting industries. This is also consistent with some previous findings, and suggests that those that feel their livelihoods threatened by increased regulation will oppose it. Political ideology (as measured by the percent who vote Democrat) also appears to have an impact on the local environment, as in the work of Kahn, but voter turnout - a measure of a populace's potential for political action, introduced into this literature by Hamilton (1993) - generally does not exhibit the hypothesized effect.

Larger per capita income is found to have a positive effect on the APA expenditure of plants, consistent with the notion that the environment is a normal good and/or that plants abate more in areas where potential economic damages are higher. Few of the other variables related to would-be compensation, however, such as population density, education, and home value, are found to have the expected effects. And in terms of "environmental injustice," there is mixed evidence that plants in areas with large nonwhite and/or foreign-born populations have significantly different APA expenditures.

In the next section, the role of community characteristics in local environmental outcomes is discussed, as is some of the relevant literature. Section III contains a discussion of the data and the 
empirical specification. Results are presented in Section IV, followed by a section of concluding remarks.

\section{The Role of Community CharaCteristics}

Much of the previous literature has explored the apparent correlation between minority populations and local pollution levels and the siting of polluting facilities. Several recent studies have begun debunking the notion of "environmental racism," finding that other factors - some correlated with race - may play a more dominant role.

Hamilton (1993), for example, examines the expansion plans of hazardous waste processing facilities and finds that a county's potential for collective action (as measured by voter turnout) is the most influential community characteristic in determining where noxious activities were (and were not) sited - demand, supply, and factor costs being equal. "Coasian" variables related to the would-be compensation from environmental damages (e.g., median household income, house value, college education, population density, and urban population) are generally found not to have an effect, with the exception perhaps on sitings prior to the mid-1980s. A county's racial (nonwhite) composition does not matter in the principle specifications, but may have played a role in which sites had planned contractions.

In Hamilton (1995), he performs similar analyses at the zip code level while expanding the set of community characteristics examined. Again, the primary explanation is the threat of collective action (i.e., political opposition). The only economic characteristics that ever matter are total population (i.e., the number of potential "victims") and the percent of the population that rents (i.e., a proxy for attachment to a locale and sunk costs). As before, race is not a statistically significant factor in the regression analyses even though nonwhite population and hazardous waste capacity 
expansion are positively correlated. "Pure discrimination" therefore is not a likely explanation.

Kriesel et al. (1996) continue this line of investigation by exploring toxic emissions inside Census block groups in Georgia and Ohio. The authors show that statistical evidence of environmental racism disappears as explanatory variables are added to the analysis. In the end, only poverty rate, educational attainment, and the presence of an interstate highway (an industrial location factor) helped explain local exposure to toxic pollutants. Voter turnout had an effect that was opposite of what Hamilton found, and house value, population density, and manufacturing employment had no statistically significant effect. The authors also explore the toxic releases of new hazardous waste facilities and find that race and income do not matter, while voter turnout continues to have a positive effect, as does interstate highways. Population density has a negative effect on toxic emissions, and there is some evidence that average house value also has a negative effect.

More recently, Arora \& Cason (1999) examined toxic emissions at the zip code level, employing a sample selection model and a long list of local economic, demographic, and political characteristics. No strong, consistent results emerge across areas of the country. Race matters, but only under very specific conditions: "non-urban" areas of the South. A number of economic and "political" variables also matter in the South, such as household income, housing vacancy, unemployment, and the percent who rent homes. There are much fewer significant factors outside the South, limited (at times) to percent foreign-born, educational attainment, and total population. The political / collective action variables are generally either statistically insignificant or wrongsigned.

Like the previous two papers, Kahn (1997b) also looks at toxic emissions using data from

\footnotetext{
1 Wolverton (2002) also finds that race and the location of TRI facilities (in Texas) are currently positively correlated, but finds no such correlation at the time of siting. This suggests some sort of ex post sorting. Perhaps the presence of such facilities suppresses local property values, subsequently attracting populations with lower incomes.
} 
EPA's Toxics Release Inventory. He also examines county-level ambient air quality with respect to two pollutants: particulates and sulfur dioxide. In this study, the effects of local economic and political characteristics (per capita income, manufacturing's share of local employment, percent who voted Democrat, college graduates, and population density) are only of secondary interest, meant to control for differential regulatory enforcement across counties as well as notions of "Coasian" compensation (see Hamilton 1993). Nonetheless, there is some evidence that all these factors matter, in the expected ways.

Other strands of literature have focused on quite different environmental outcomes. Gray \& Deily (1996), for example, look at air pollution inspections and enforcement actions taken against U.S. steel mills. They hypothesize that regulators may be more reluctant to act against plants when the political costs are high — for example, when the firm accounts for a large share of the locale's total employment and/or there is high unemployment in the county. They find strong evidence that at least the former is true.

Meanwhile, Kahn \& Matsusaka (1997) examine cross-county voting outcomes in the State of California with respect to 16 environment-related ballot initiatives, including ones on toxic disclosure, environmental protection \& conservation, expanding parklands, pesticide bans, etc. Here, the environment is treated as (and found to behave much like) any other good: its demand is driven by both income and "prices". In particular, the authors find that many of these "goods" are normal at mean income levels and inferior (perhaps) at higher incomes. Prices are proxied by measures of "self-interest" - namely, the share of local employment and income derived from affected sectors (e.g., manufacturing, construction, farming, and/or forestry) as well as the educational attainment of the populace (i.e., a measure of potential worker displacement). These price variables had their expected effect in the majority of cases. There is also an added effect from political ideology - or "preferences" - as measured by the percent who register or vote Democrat. 
In this study, I examine expenditures on air pollution abatement by manufacturing establishments and the effect community characteristics have on the decisions of these plants (and/or the regulators who regulate them). I draw upon the above literature for local factors that may influence this outcome as well as contribute a few new variables to the usual mix. They can be broadly (and somewhat arbitrarily) classified as belonging to one of four groups: (1) political / "selfinterest" variables, (2) income and preferences, (3) “Coasian" compensation variables, and (4) other factors driving regulators and/or facilities. These variables are described briefly in Table 1 and (highlighted and) further discussed below. As in Hamilton (1993), Gray \& Deily (1996), Kahn \& Matsusaka (1997), and Kahn (1997b), my geographic unit of analysis is the county.

In terms of the first group, some local constituencies may demand that their regulators adopt policies more stringent than required by their state or federal government (e.g., under the Clean Air Act). A higher density of population surrounding a plant, for example, may increase the pressure placed on it since its emissions (left unabated) adversely affects that many more people. And homeowners in particular may demand greater pollution abatement efforts from their nearby plants; numerous studies have demonstrated a relationship between ambient air quality and property values (e.g., Chay \& Greenstone 2000). Other groups, however, may be more hostile to additional environmental protection. The unemployed and those engaged in manufacturing, in particular, may feel their very livelihoods threatened by increased regulation. And, as in several of the cited studies, I also include voter turnout as a measure of a populace's ability to take collective action.

Apart from these potential political factors, the demand for environmental quality, like that for any other good, may simply derive from income and preferences. If environmental protection is indeed a normal good, wealthier counties (as measured by per capita income) might be expected to press for stricter requirements on their polluting plants. Demand might also be expected to depend on one's vulnerability to air pollution, and the EPA has identified children and the elderly among 
Table 1. Description of county characteristics

\begin{tabular}{|c|c|c|}
\hline & $\begin{array}{c}\text { Mean } \\
\text { (Std. Dev.) }\end{array}$ & Description \\
\hline Population density & $\begin{array}{c}1,611 \\
(5,446)\end{array}$ & Persons per square mile. \\
\hline Homeownership & $\begin{array}{c}65.8 \\
(10.7)\end{array}$ & $\begin{array}{l}\text { Percent of occupied housing units that are } \\
\text { owner-occupied. }\end{array}$ \\
\hline Unemployment & $\begin{array}{c}6.66 \\
(2.39)\end{array}$ & $\begin{array}{l}\text { Percent of civilian labor force ( } 16 \text { years and older) } \\
\text { that is unemployed. }\end{array}$ \\
\hline Manufacturing & $\begin{array}{l}26.2 \\
(9.3)\end{array}$ & $\begin{array}{l}\text { Percent of employed civilian labor force (16 years } \\
\text { and older) employed in manufacturing. }\end{array}$ \\
\hline Voter turnout & $\begin{array}{l}53.6 \\
(8.4)\end{array}$ & $\begin{array}{l}\text { Percent of voting-age population that cast a vote } \\
\text { for president (1980). }\end{array}$ \\
\hline Income & $\begin{array}{c}7,271 \\
(1,301)\end{array}$ & Per capita money income (in dollars). \\
\hline Sensitive population & $\begin{array}{l}18.4 \\
(2.6)\end{array}$ & $\begin{array}{l}\text { Percent of population under } 5 \text { years of age or } 65 \\
\text { years and over. }\end{array}$ \\
\hline Doctors & $\begin{array}{c}195 \\
(139)\end{array}$ & $\begin{array}{l}\text { Active, non-federal physicians per } 100,000 \\
\text { population (1985). }\end{array}$ \\
\hline Democrats & $\begin{array}{l}40.5 \\
(10.2)\end{array}$ & $\begin{array}{l}\text { Percent of (major party) votes cast for Democratic } \\
\text { presidential candidate (1984). }\end{array}$ \\
\hline Poverty & $\begin{array}{l}9.15 \\
(4.10)\end{array}$ & Percent of families below the poverty level. \\
\hline Education & $\begin{array}{l}15.6 \\
(6.0)\end{array}$ & $\begin{array}{l}\text { Percent of population ( } 25 \text { years and older) with } \\
\text { at least a bachelor's degree. }\end{array}$ \\
\hline Home value & $\begin{array}{c}48,638 \\
(18,929)\end{array}$ & $\begin{array}{l}\text { Median value of owner-occupied } \\
\text { non-condominium housing units (in dollars). }\end{array}$ \\
\hline Nonwhite & $\begin{array}{c}15.8 \\
(13.5)\end{array}$ & Percent of population that is nonwhite. \\
\hline Foreign-born & $\begin{array}{l}5.3 \\
(5.8)\end{array}$ & Percent of population that is foreign-born. \\
\hline Polluters & $\begin{array}{c}93 \\
(38)\end{array}$ & $\begin{array}{l}\text { "Polluting" manufacturing establishments per } \\
100,000 \text { population (1982). }\end{array}$ \\
\hline Metropolitan area & .766 & County is in an MSA (June 1998 definition). \\
\hline
\end{tabular}


those particularly at risk. ${ }^{2}$ I further proxy for a county's “taste for health" by observing the number of active physicians per capita. Finally, I also allow political ideology to shape a county's preference for environmental protection. Here, as in Kahn \& Matsusaka (1997), this is measured by the percent of (major party) votes cast for the Democratic presidential candidate.

An establishment may consider would-be compensation for environmental damages posed by its operation in deciding where to locate and how much to invest in pollution abatement. Areas with high rates of poverty and/or low levels of educational attainment may result in lower damages being awarded in the event of injuries and/or deaths from accidental exposure. Similarly, litigation may result in compensation for reduced property values. Here, I include the median value of houses in the county. Population density and per capita income (mentioned previously) are also likely to be considered Coasian-type variables.

Other local characteristics may also explain the "supply" of environmental protection. As noted, much has been written on the issue of "environmental injustice" (a.k.a. environmental inequity, racism, discrimination, etc.) — the notion that polluting facilities are more likely to be situated near minority communities and/or toxic emissions are higher in such areas. Here, I allow for the possibility of such discrimination on the part of firms - and obviously, by extension, regulators - by including the nonwhite proportion of a county's population and the percent that is foreign-born. Unequal regulatory treatment and dissimilar pollution abatement expenditure, however, may also be due to disparate caseloads among local regulators. One might expect, for example, all else being equal, that a plant in a region with more polluters may face a lower probability of being inspected and perceive a greater opportunity to shirk environmental obligations. A measure of "polluters" per capita is meant, in part, to capture this effect. Whether a plant is in a metropolitan statistical area - where regulators are likely based - is also a potential factor.

${ }^{2}$ Gray and Shadbegian (forthcoming) indeed show that pulp and paper mills that are surrounded by larger proportions of kids and elders have lower sulfur dioxide $\left(\mathrm{SO}_{2}\right)$ and particulate $(\mathrm{PM}-10)$ emissions. 
Table 2 shows the correlation coefficients between plant-level air pollution abatement activity (as defined by the measure described in the next section) and these community characteristics. Seven of the sixteen correlations are statistically significant, with homeownership and unemployment positively related to air pollution abatement expenditure, and income, doctors, education, home value, and metropolitan area status negatively correlated. With the exception of homeownership, the direction of these statistically significant correlations are the opposite of what might be hypothesized; however, multiple regression analysis is obviously the much more appropriate way to explore these various relationships.

\section{Table 2. Correlation between APA operating costs per dollar of output and county} characteristics

\begin{tabular}{|l|c|}
\hline Population density & -0.0026 \\
\hline Homeownership & $+0.0064^{*}$ \\
\hline Unemployment & $+0.0092^{* *}$ \\
\hline Manufacturing & -0.0026 \\
\hline Voter turnout & -0.0008 \\
\hline Income & $-0.0088^{* *}$ \\
\hline Sensitive population & +0.0042 \\
\hline Doctors & $-0.0055^{*}$ \\
\hline Democrats & -0.0000 \\
\hline Poverty & +0.0047 \\
\hline Education & $-0.0071^{* *}$ \\
\hline Home value & $-0.0075^{* *}$ \\
\hline Nonwhite & -0.0022 \\
\hline Foreign-born & -0.0043 \\
\hline Polluters & -0.0040 \\
\hline Metropolitan area & $-0.0094^{* *}$ \\
\hline
\end{tabular}

** Significant at the 5\% level. * Significant at the $10 \%$ level. 


\section{DATA AND METHOdOlOgY}

With a few exceptions, the county-level variables in Table 1 and discussed above are based on data from the 1980 Census of Population and Housing and extracted from the Census Bureau's USA Counties 1998 (CD-ROM). ${ }^{3} \quad$ The underlying voting data were compiled by the Elections Research Center, while the number of physicians is based on data assembled by the American Medical Association from its Physician Masterfile (and extracted from the Census Bureau's County and City Data Book 1988). The "polluters" variable was constructed using 1982 Census of Manufactures microdata and the definition of high air pollution emitting industries from Becker (2001).

The establishment-level data for this study come from the Census Bureau's Pollution Abatement Costs and Expenditures (PACE) surveys of 1979-1982, 1984-1986, and 1988. My particular variable of interest is air pollution abatement operating costs, which includes salaries \& wages, parts \& materials, fuel \& electricity, capital depreciation, contract work, equipment leasing, and so forth associated with a plant's abatement of air pollution in that calendar year. ${ }^{4}$ To this I merge data that these plants may have reported in the contemporaneous Annual Survey of Manufactures (ASM). The ASM data provide me with some important, basic information on these plants, including establishment employment, value of output, total operating costs, location, industry, age, ownership, and so forth. ${ }^{5}$ After restricting my attention to cases that were in both the PACE and ASM samples in a given year, and after eliminating survey non-respondents, certain item nonrespondents, non-manufacturing establishments, inactive cases, and so forth, I am left with 89,889

\footnotetext{
3 The local characteristics these various variables attempt to capture are, for the most part, ones that are unlikely to have changed very much, or in important ways, during the time period under study here. They are therefore treated as timeinvariant in the specification below. To mitigate endogeneity concerns, the explanatory variables generally predate the expenditure being analyzed.

${ }^{4}$ See U.S. Bureau of the Census (19__ for additional details.

5 The establishment-level survey data in both the PACE and ASM are confidential, collected and protected under Title 13 of the U.S. Code. Restricted access to these data can be arranged through the Census Bureau's Center for Economic Studies. See http://www.ces.census.gov/ for details.
} 
plant-years of observations for my empirical analyses. Becker (2001) contains a fuller description of the research sample, variable construction, and such.

Besides community characteristics, establishments' air pollution abatement (APA) expenditures may be driven by a host of other factors. Outlays, for example, will obviously depend on the size of the establishment. I therefore define my dependent variable as

$$
A P A \text { intensity }_{i}=\left(A P A_{i} / Q_{i}\right)
$$

where $i$ indexes an establishment; $A P A$ is dollars of air pollution abatement operating costs; and $Q$ is dollars of output. ${ }^{6,7}$ This too may vary by the size of the plant, however, if for example there are returns to scale in pollution abatement. Establishment employment (and employment squared), therefore, will be used as control variables in the empirical analyses. Other establishment characteristics possibly affecting the intensity of APA activity are the age of the plant and whether or not it belongs to a multi-plant firm. The former will be represented by a series of dummy variables indicating the time elapsed since the establishment's first appearance in the Census of Manufactures (conducted every five years); the latter is captured by a simple dummy variable. I also control for plant productivity, as measured by real value added per worker, using data from the ASM.

Regulation obviously also plays a role in determining how much APA is done by plants. At the national level, certain industries are inherently more polluting and are therefore regulated more intensely. Here, I control for the stringency of this regulation with an industry-level air pollution intensity index constructed using the IPPS air emissions coefficients described by Hettige et al. (1994). In particular, for each 4-digit SIC industry, I sum the estimates of pounds of emissions per dollar of output for sulfur dioxide $\left(\mathrm{SO}_{2}\right)$, nitrogen dioxide $\left(\mathrm{NO}_{2}\right)$, carbon monoxide $(\mathrm{CO})$, total

\footnotetext{
${ }^{6}$ Output in the ASM is measured by total value of shipments adjusted for net changes to inventory and the value of products resold as originally purchased.

7 The mean APA intensity in this sample is 0.00242 (i.e., APA operating costs are $0.242 \%$ of total output) with a standard deviation of 0.06356 . In all, there is about $\$ 28.5$ billion worth of APA operating costs in this sample (in 1988 dollars).
} 
suspended particulates (TSP), and volatile organic compounds (VOC) - all pollutants covered under the Clean Air Act. ${ }^{8}$ Beyond this "federal" regulation, there is also state-level variation in environmental regulations, and a number of indexes measuring the relative stringency of such regulation have been developed, some of which even employ data from the PACE survey (see Levinson 2001 for a review). Here, however, I will simply use state dummy variables to control for interstate differences in regulation.

Below the state level, the Clean Air Act requires that all locales achieve the National Ambient Air Quality Standards (NAAQS) set for the six "criteria" air pollutants. A growing literature is finding that county-level non-attainment of these NAAQS significantly impacts heavy air polluters, presumably through more stringent regulation (e.g., Henderson 1996; Kahn 1997a; Becker \& Henderson 2000, 2001; List \& McHone 2000; Becker 2001; Greenstone 2002). Here, I control for this "local" regulation through a series of indicator variables, indicating whether the establishment is a high emitter of any of the criteria air pollutants in a county that is non-attainment of the NAAQS for the respective pollutant(s).

To summarize, plant-level air pollution abatement operating costs, as specified in equation (1), are modeled as a function of the community characteristics that are of interest in this study, establishment characteristics, and regulation from various sources. Year effects are also incorporated. A double log functional form is assumed here, and since the value of dependent variable is bounded from below, Tobit specifications are employed. ${ }^{9}$ The next section will present results, first using only community characteristics as explanatory variables, then adding plant

\footnotetext{
${ }^{8}$ Note that equal weight is given to each of these pollutants though their actual toxicities may differ. Also, the IPPS data come on the 1987 SIC basis while the establishments in my sample are classified according to 1972 SIC definitions. The IPPS data are converted to the 1972 SIC basis using a 1987-1972 SIC concordance table with shipment weights. Data are missing for about a dozen of the 450 or so industries. These industries will be treated with dummy variables instead. ${ }^{9}$ In particular, establishments are asked to report their APA expenditures in thousands of dollars. Therefore, with rounding, an entry of zero reflects expenditures of less than $\$ 500$. The cnreg (censored normal regression) command in Stata 7.0 is a generalization of the standard Tobit procedure that allows the censoring point to vary by observation. In this case, left-censoring occurs at $\ln \left(0.5 / Q_{i}\right)$ for about $53.5 \%$ of the plants in this sample.
} 
characteristics and state and county regulation. Results are presented for both the full sample as well as for a subsample of establishments that are particularly heavy air polluters. In particular, (approximately) the top quartile of plants - in terms of their air pollution intensity index - are analyzed separately. These plants should be the most sensitive to the factors under examination here. Some 100 unique 4-digit SIC industries are represented in this subsample, compared to 435 in the full sample.

\section{RESULTS}

Table 3 contains results for the full sample of establishments; Table 4 contains results for the subsample of high polluters. In each table, the first column presents model coefficients controlling only for industry effects (via the air pollution intensity index described above) and year effects. The model in the second column adds establishment-level controls (i.e., employment and employment squared, age variables, productivity, and a dummy variable indicating "multi-unit" plants). The model in the third column additionally controls for state-level effects (including differences in air quality regulation between states) via state dummy variables, as well as county-level regulation resulting from the Clean Air Act (i.e., indicators of county NAAQS non-attainment of the respective criteria air pollutants and interactions between county non-attainment statuses and indicators of whether the establishment is a "high emitter" of the respective air pollutants). Statistically significant coefficients at the $10 \%$ and $5 \%$ levels are indicated by single and double asterisks respectively.

In Table 3, most of the coefficients on the community characteristics are statistically significant. Most of these effects, however, are opposite of what might be expected. Among the expected effects, higher rates of homeownership are found to increase APA expenditure, as are higher incomes, higher propensities to vote Democrat, and being in a metropolitan statistical area. And once the fuller set of controls are in place, in column 3, APA activity is also found to be lower in 
Table 3. APA operating costs per dollar of output (in natural logs): Full sample

\begin{tabular}{|c|c|c|c|}
\hline & $(1)$ & $(2)$ & (3) \\
\hline $\ln$ (Population density) & $\begin{array}{l}\mathbf{- 0 . 1 2 0}{ }^{* *} \\
(0.019)\end{array}$ & $\begin{array}{l}\mathbf{- 0 . 0 9 5} \mathbf{5}^{* *} \\
(0.019)\end{array}$ & $\begin{array}{l}\mathbf{- 0 . 1 3 9 * *} \\
(0.025)\end{array}$ \\
\hline $\ln$ (Homeownership) & $\begin{array}{c}+1.312^{* *} \\
(0.126)\end{array}$ & $\begin{array}{l}+\mathbf{+ 1 . 3 7 3 * *} \\
(0.128)\end{array}$ & $\begin{array}{c}\mathbf{+ 0 . 8 3 5 * *}^{* *} \\
(0.147)\end{array}$ \\
\hline $\ln$ (Unemployment) & $\begin{array}{c}+\mathbf{0 . 2 7 8}^{* *} \\
(0.053)\end{array}$ & $\begin{array}{c}+\mathbf{0 . 2 1 0} * * \\
(0.053)\end{array}$ & $\begin{array}{c}\mathbf{+ 0 . 1 7 3}^{* *} \\
(0.080)\end{array}$ \\
\hline $\ln$ (Manufacturing) & $\begin{array}{l}+\mathbf{0 . 4 0 5 * *} \\
(0.051)\end{array}$ & $\begin{array}{r}+\mathbf{0 . 0 5 4} \\
(0.052)\end{array}$ & $\begin{array}{c}+\mathbf{0 . 2 3 5}^{* *} \\
(0.064)\end{array}$ \\
\hline $\ln ($ Voter turnout $)$ & $\begin{array}{l}\mathbf{- 0 . 5 0 9 * *} \\
(0.127)\end{array}$ & $\begin{array}{l}\mathbf{- 0 . 6 2 9 * *} \\
(0.128)\end{array}$ & $\begin{array}{r}+\mathbf{+ 0 . 2 5 0} \\
(0.187) \\
\end{array}$ \\
\hline $\ln$ (Income) & $\begin{array}{c}+\mathbf{2 . 3 5 0 * *} \\
(0.222) \\
\end{array}$ & $\begin{array}{l}+1.668^{* *} \\
(0.226)\end{array}$ & $\begin{array}{c}+\mathbf{+ 0 . 6 6 8 * *} \\
(0.288) \\
\end{array}$ \\
\hline $\ln$ (Sensitive population) & $\begin{array}{l}\mathbf{- 0 . 8 3 2 * *} \\
(0.162)\end{array}$ & $\begin{array}{l}\mathbf{- 0 . 7 2 4 * *} \\
(0.163)\end{array}$ & $\begin{array}{l}\mathbf{- 1 . 0 4 4 * *} \\
(0.185)\end{array}$ \\
\hline $\ln$ (Doctors) & $\begin{array}{c}+\mathbf{+ 0 . 1 4 0}^{* *} \\
(0.037) \\
\end{array}$ & $\begin{array}{r}+\mathbf{+ 0 . 0 5 3} \\
(0.037) \\
\end{array}$ & $\begin{array}{r}\mathbf{+ 0 . 0 5 0} \\
(0.039) \\
\end{array}$ \\
\hline $\ln$ (Democrats) & $\begin{array}{c}+\mathbf{0 . 1 4 2}^{*} \\
(0.073)\end{array}$ & $\begin{array}{r}+\mathbf{0 . 1 4 1}^{*} \\
(0.073)\end{array}$ & $\begin{array}{c}\mathbf{+ 0 . 3 6 3 * *} \\
(0.088)\end{array}$ \\
\hline $\ln$ (Poverty) & $\begin{array}{c}+\mathbf{0 . 4 5 7 * *} \\
(0.085) \\
\end{array}$ & $\begin{array}{c}\mathbf{+ 0 . 3 8 9 * *} \\
(0.086) \\
\end{array}$ & $\begin{array}{c}+\mathbf{0 . 1 7 4 *} \\
(0.104) \\
\end{array}$ \\
\hline $\ln ($ Education $)$ & $\begin{array}{l}-\mathbf{- 0 . 4 4 7 * *} \\
(0.089)\end{array}$ & $\begin{array}{l}\mathbf{- 0 . 5 8 8 ^ { * * }} \\
(0.090)\end{array}$ & $\begin{array}{l}\mathbf{- 0 . 3 0 3 * *} \\
(0.099)\end{array}$ \\
\hline $\ln$ (Home value) & $\begin{array}{l}\mathbf{- 0 . 1 8 9 * *} \\
(0.086)\end{array}$ & $\begin{array}{r}+\mathbf{+ 0 . 0 1 9} \\
(0.087)\end{array}$ & $\begin{array}{l}\mathbf{- 0 . 1 3 9} \\
(0.146)\end{array}$ \\
\hline $\ln$ (Nonwhite) & $\begin{array}{l}\mathbf{- 0 . 0 1 7} \\
(0.020)\end{array}$ & $\begin{array}{l}\mathbf{- 0 . 0 2 6} \\
(0.021) \\
\end{array}$ & $\begin{array}{l}-\mathbf{0 . 0 6 3}{ }^{* *} \\
(0.026)\end{array}$ \\
\hline $\ln ($ Foreign-born $)$ & $\begin{array}{l}+\mathbf{+ 0 . 1 0 6 * *} \\
(0.025)\end{array}$ & $\begin{array}{c}+0.127^{* *} \\
(0.025)\end{array}$ & $\begin{array}{c}\mathbf{+ 0 . 0 8 9 * *} \\
(0.039)\end{array}$ \\
\hline $\ln$ (Polluters) & $\begin{array}{l}\mathbf{- 0 . 3 6 8 * *} \\
(0.044)\end{array}$ & $\begin{array}{l}\mathbf{- 0 . 0 9 5 * *} \\
(0.045)\end{array}$ & $\begin{array}{l}-\mathbf{- 0 . 0 0 5} \\
(0.048)\end{array}$ \\
\hline Metropolitan area $(=1)$ & $\begin{array}{c}+\mathbf{0 . 2 1 1} 1^{* *} \\
(0.047)\end{array}$ & $\begin{array}{c}+\mathbf{0 . 1 9 4 * *} \\
(0.048)\end{array}$ & $\begin{array}{c}+\mathbf{0 . 1 4 0 * *} \\
(0.049)\end{array}$ \\
\hline Constant & yes & yes & yes \\
\hline Year effects & yes & yes & yes \\
\hline $\begin{array}{l}\text { Industry effects: } \\
\quad \ln (\text { Emissions per employee })\end{array}$ & $\begin{array}{c}+\mathbf{0 . 7 2 7}^{* *} \\
(0.006)\end{array}$ & $\begin{array}{c}+\mathbf{0 . 7 2 7}^{* *} \\
(0.006)\end{array}$ & $\begin{array}{c}\mathbf{+ 0 . 6 2 6}^{* *} \\
(0.007)\end{array}$ \\
\hline Establishment characteristics & no & yes & yes \\
\hline State effects & no & no & yes \\
\hline County-level regulation & no & no & yes \\
\hline Pseudo $\mathrm{R}^{2}$ & 0.0635 & 0.0737 & 0.0804 \\
\hline Observations & 89,889 & 89,889 & 89,889 \\
\hline
\end{tabular}

** Significant at the $5 \%$ level. * Significant at the $10 \%$ level. 
in counties with larger nonwhite population, suggesting environmental injustice. The percent of the population that is foreign-born, however, is found to have the opposite effect on environmental expenditures. Also having effects opposite of what is expected are population density, unemployment, manufacturing, vulnerable populations, poverty, and educational attainment. The coefficient on voter turnout, meanwhile, has the expected sign (only after state and county-level regulation is controlled for) but does not quite attain statistical significance. And the number of other local air polluters per capita has the right sign and was statistically significant until those final controls were put in place.

This mix of expected and unexpected results using the full sample can be puzzling. However, it is important to note that most of the plants in this sample are not large air polluters and their motivations for APA expenditure (to the extent that they have any at all) may be quite different than those that are particularly high emitters. To illustrate this point, I estimate plant-level emissions of the five criteria air pollutants $\left(\mathrm{SO}_{2}, \mathrm{NO}_{2}, \mathrm{CO}\right.$, TSP, and VOC), multiplying the industry-level IPPS emission factors (for employment) by total establishment employment. The median plant in this sample is found to have just 22 tons of emissions of all criteria pollutants. ${ }^{10}$ This is far less than what the EPA usually lists as a "major" source, which generally requires at least 100 tons of emissions per year of at least one of these air pollutants. Hence, Table 4 focuses on just the highest emitting industries. The median emissions in this group is over 700 tons per plant per year.

We see in column 1 of Table 4 that most of these sixteen community characteristics have a statistically significant effect on plant-level APA operating costs, including eight that have their hypothesized effect. Of those that don't have their expected effect: Increased voter turnout is found to decrease APA expenditure. Its statistical significance diminishes however once plant characteristics and state and county regulation are controlled for (in column 3) though it still has a $t$ -

10 These are lower bound estimates, as explained in Hettige et al. (1994). 
Table 4. APA operating costs per dollar of output (in natural logs): High air polluters

\begin{tabular}{|c|c|c|c|}
\hline & (1) & (2) & (3) \\
\hline $\ln$ (Population density) & $\begin{array}{c}+\mathbf{+ 0 . 0 6 9} * * \\
(0.027) \\
\end{array}$ & $\begin{array}{c}+\mathbf{0 . 0 8 2} * * \\
(0.027) \\
\end{array}$ & $\begin{array}{c}\mathbf{- 0 . 0 0 8} \\
(0.037) \\
\end{array}$ \\
\hline $\ln$ (Homeownership) & $\begin{array}{c}+1.107^{* *} \\
(0.273) \\
\end{array}$ & $\begin{array}{c}+\mathbf{0 . 9 2 6}^{* *} \\
(0.272) \\
\end{array}$ & $\begin{array}{c}\mathbf{+ 0 . 7 9 2 * *} \\
(0.303)\end{array}$ \\
\hline $\ln ($ Unemployment $)$ & $\begin{array}{c}\mathbf{- 0 . 0 1 5} \\
(0.073) \\
\end{array}$ & $\begin{array}{c}\mathbf{- 0 . 0 7 8} \\
(0.073) \\
\end{array}$ & $\begin{array}{c}\mathbf{- 0 . 1 5 0} \\
(0.108) \\
\end{array}$ \\
\hline $\ln$ (Manufacturing) & $\begin{array}{l}\mathbf{- 0 . 3 2 2 * *} \\
(0.073) \\
\end{array}$ & $\begin{array}{l}\mathbf{- 0 . 5 3 7 * *} \\
(0.074) \\
\end{array}$ & $\begin{array}{l}-\mathbf{- 0 . 2 2 1}^{* *} \\
(0.088) \\
\end{array}$ \\
\hline $\ln ($ Voter turnout $)$ & $\begin{array}{l}\mathbf{- 0 . 3 4 5}^{* *} \\
(0.175) \\
\end{array}$ & $\begin{array}{l}\mathbf{- 0 . 3 4 6}^{* *} \\
(0.174)\end{array}$ & $\begin{array}{c}\mathbf{- 0 . 3 6 6} \\
(0.253) \\
\end{array}$ \\
\hline $\ln$ (Income) & $\begin{array}{c}+2.506^{* *} \\
(0.320) \\
\end{array}$ & $\begin{array}{c}+\mathbf{+ 2 . 0 8 5}{ }^{* *} \\
(0.321) \\
\end{array}$ & $\begin{array}{c}\mathbf{+ 0 . 8 0 3} * \\
(0.428) \\
\end{array}$ \\
\hline $\ln$ (Sensitive population) & $\begin{array}{r}+\mathbf{+ 0 . 0 0 3} \\
(0.233) \\
\end{array}$ & $\begin{array}{r}\mathbf{+ 0 . 1 7 9} \\
(0.233) \\
\end{array}$ & $\begin{array}{r}\mathbf{+ 0 . 0 8 8} \\
(0.267) \\
\end{array}$ \\
\hline $\ln$ (Doctors) & $\begin{array}{c}\mathbf{- 0 . 0 3 1} \\
(0.049)\end{array}$ & $\begin{array}{l}\mathbf{- 0 . 1 0 9} \mathbf{9}^{* *} \\
(0.049)\end{array}$ & $\begin{array}{c}\mathbf{- 0 . 0 7 2} \\
(0.051)\end{array}$ \\
\hline $\ln$ (Democrats) & $\begin{array}{c}+\mathbf{0 . 3 8 7} * * \\
(0.104)\end{array}$ & $\begin{array}{c}+\mathbf{0 . 3 4 1} * * \\
(0.104)\end{array}$ & $\begin{array}{c}\mathbf{+ 0 . 4 9 0}^{* *} \\
(0.123)\end{array}$ \\
\hline $\ln$ (Poverty) & $\begin{array}{c}+\mathbf{0 . 1 6 4} \\
(0.123) \\
\end{array}$ & $\begin{array}{c}+\mathbf{+ 0 . 1 4 7} \\
(0.122) \\
\end{array}$ & $\begin{array}{c}+\mathbf{+ 0 . 0 2 1} \\
(0.151) \\
\end{array}$ \\
\hline $\ln ($ Education $)$ & $\begin{array}{l}\mathbf{- 0 . 6 0 5 * *} \\
(0.118) \\
\end{array}$ & $\begin{array}{l}\mathbf{- 0 . 6 5 0 * *} \\
(0.117) \\
\end{array}$ & $\begin{array}{l}\mathbf{- 0 . 1 7 5} \\
(0.131) \\
\end{array}$ \\
\hline $\ln ($ Home value $)$ & $\begin{array}{l}\mathbf{- 0 . 1 2 6} \\
(0.126)\end{array}$ & $\begin{array}{c}+\mathbf{0 . 0 9 1} \\
(0.126)\end{array}$ & $\begin{array}{l}-\mathbf{- 0 . 0 4 2} \\
(0.198)\end{array}$ \\
\hline $\ln$ (Nonwhite) & $\begin{array}{c}+\mathbf{+ 0 . 0 7 9} * * \\
(0.028) \\
\end{array}$ & $\begin{array}{c}+\mathbf{0 . 0 7 9} * * \\
(0.028) \\
\end{array}$ & $\begin{array}{l}\mathbf{- 0 . 0 3 0} \\
(0.035) \\
\end{array}$ \\
\hline $\ln ($ Foreign-born) & $\begin{array}{l}\mathbf{- 0 . 0 8 4 * *} \\
(0.035)\end{array}$ & $\begin{array}{c}-\mathbf{0 . 0 7 1 *} \\
(0.035)\end{array}$ & $\begin{array}{r}\mathbf{+ 0 . 0 0 2} \\
(0.053) \\
\end{array}$ \\
\hline $\ln$ (Polluters) & $\begin{array}{c}\mathbf{- 0 . 2 0 3 * *} \\
(0.058) \\
\end{array}$ & $\begin{array}{c}\mathbf{- 0 . 0 4 2} \\
(0.059)\end{array}$ & $\begin{array}{l}\mathbf{- 0 . 0 1 3} \\
(0.065)\end{array}$ \\
\hline Metropolitan area $(=1)$ & $\begin{array}{c}+\mathbf{0 . 1 7 3}^{* *} \\
(0.065) \\
\end{array}$ & $\begin{array}{c}+\mathbf{+ 0 . 1 7 0}^{* *} \\
(0.064) \\
\end{array}$ & $\begin{array}{r}+\mathbf{+ 0 . 1 3 1 *} \\
(0.067) \\
\end{array}$ \\
\hline Constant & yes & yes & yes \\
\hline Year effects & yes & yes & yes \\
\hline $\begin{array}{l}\text { Industry effects: } \\
\qquad \ln (\text { Emissions per employee })\end{array}$ & $\begin{array}{l}+1.040 * * \\
(0.022)\end{array}$ & $\begin{array}{c}+0.963 * * \\
(0.023) \\
\end{array}$ & $\begin{array}{c}\mathbf{+ 0 . 8 6 5 * *} \\
(0.025) \\
\end{array}$ \\
\hline Establishment characteristics & no & yes & yes \\
\hline State effects & no & no & yes \\
\hline County-level regulation & no & no & yes \\
\hline Pseudo $\mathrm{R}^{2}$ & 0.0292 & 0.0354 & 0.0426 \\
\hline Observations & 22,516 & 22,516 & 22,516 \\
\hline
\end{tabular}

** Significant at the 5\% level. * Significant at the $10 \%$ level. 
statistic of 1.45. Only Hamilton $(1993,1995)$ has really ever found this factor to have a positive effect on the local environment. Educational attainment is also found to have a statistically significant negative effect on APA activity in a community, but this too becomes statistically zero once state dummies and county-level regulation are added to the specification. Meanwhile, higher nonwhite populations are found to increase local APA expenditure, while the percent foreign-born is actually found to decrease such spending. Neither of these effects is statistically significant in the final specification however, suggesting little evidence of "environmental discrimination" among these highest polluters.

Population density is found to have a positive effect on APA activity, as might be expected. However, once state and county regulation are controlled for, this effect goes away. High density areas therefore enjoy additional abatement activity in their local plants, but only because they tend to be in states and counties that are heavily regulated anyway, not because these populaces can muster up more political opposition or because plants are insuring against greater potential damages. The number of other air polluters in the county - meant to capture the potential distraction of regulators - has a negative effect on APA expenditures, but not after one controls for plant-specific characteristics. The implication is that establishments in areas with many other polluting plants per capita tend to be - as it turns out - smaller, younger, less productive, and/or more likely to be "single unit" establishments. Sensitive populations (the young and elderly), the number of doctors, poverty rates, median home value, and unemployment have - for the most part - no effect in any of the regressions in Table 4. The coefficient on unemployment, however, does have the correct (negative) sign and does attain statistical significance at around the 16\% level.

Meanwhile, five of these community characteristics have strong, statistically significant effects, of the expected sign, through all three of the regressions in Table 4. Indeed, these five factors are the only ones that are significant in the final specification with full controls (column 3). One should 
note that four of these five are also statistically significant (and correctly signed) throughout Table 3 as well. Among these robust results:

(1) Higher rates of homeownership are found to increase APA expenditure, consistent with the notion that constituencies will lobby to protect the value of their property. ${ }^{11}$ Other studies have found similar effects. For example, Hamilton (1995) finds that zip codes with a higher percentage of renters are more likely to experience expansions in local hazardous waste facilities. Such residents, he argues, have less attachment to a particular area and therefore may place less value on maintaining its environment. Furthermore, they have fewer "sunk costs" in the area, which means firms may need to compensate them less in the event of damages. Similarly, Arora \& Cason (1999) find that toxic emissions are higher in zip codes with higher concentration of renters, at least in the South.

(2) We also see that a heavy presence of manufacturing employment in a county reduces the amount of local APA expenditure, all else being equal. To use the language of Kahn \& Matsusaka (1997), the "price" of environmental protection is higher in such areas. Indeed, Gray \& Deily (1996) find that steel mills that accounted for a greater proportion of the local labor force faced fewer regulatory actions and inspections. Regulators, they argue, attempt to minimize the political costs of their actions, especially those that threaten the livelihoods of many employees and other local citizens. A similar effect (for similar reasons) is expected for areas with high local unemployment rates; however, the negative effect in column 3 of Table 4 does not quite attain statistical significance.

(3) Local income levels have a strong positive impact on the local environment. Different (and equally plausible) interpretations are possible. Kriesel et al. (1996) - using poverty rates instead of income - find that toxic emissions are higher in more impoverished areas and characterize this as

\footnotetext{
11 Interestingly, however, APA activity does not appear to be related to the value of homes.
} 
“discrimination against poor people.” Hamilton (1993, 1995) and Arora \& Cason (1999) - had they themselves found these effects - would have offered a "Coasian" explanation: polluters avoid polluting in areas where potential compensation for damages would be the highest. Meanwhile, Kahn \& Matsusaka (1997), in their study of voting behavior, see the environment like any other normal good: demand increases with income.

(4) Also in keeping with Kahn \& Matsusaka, the political ideology of the populace is found to have an effect on environmental outcomes. In particular, the share of major party votes cast for the Democratic presidential candidate (in this case, Walter Mondale in the 1984 election) — which is meant to measure a locale's potential support for environmental causes (traditionally thought to be the Democrats' domain) — appears to increase the APA expenditures of these polluting plants. Kahn \& Matsusaka (1997) find that this variable explains at least some of the county-level variation in voting outcomes on environmental initiatives in California, and Kahn (1997b) shows that ambient TSP concentrations and TRI emissions are often lower in areas with concentrations of Democrats. Similarly, Earnhart (2002) finds that municipal wastewater treatment facilities in Kansas experience fewer environmental inspections and release more biological oxygen demand (BOD) in areas with higher percentages of Republican voters.

(5) Finally, being in a metropolitan statistical area (MSA) increases APA outlays for these plants, all else being equal. Because I've controlled for many of the factors that are often correlated with cities (e.g., population density, race, homeownership, income, NAAQS non-attainment, etc.), one interpretation of this effect is that plants in these areas are scrutinized more intensely because regulators are more likely to be located nearby (relative to rural, non-metropolitan areas).

Table 5 shows the impact on APA intensity of a one standard deviation increase in these variables from their respective means (holding all other variables constant), using the marginal effects from the regression in column 3 of Table 4. Air pollution abatement is found to be most 
sensitive to changes in per capita income, with a standard deviation increase translating into a 13.5\% increase in APA intensity. A standard deviation increase in votes for Democrats and homeownership rates implies a $11.6 \%$ and $10.6 \%$ increase, respectively. Meanwhile, a standard deviation increase in a county's labor force engaged in manufacturing, from a mean of about $26.2 \%$, would result in a 8.0\% decrease in APA intensity. A discrete change from being located in a county outside an MSA to being in an MSA implies a $13.1 \%$ increase in air pollution abatement operating costs, all else being equal.

\section{Table 5. Marginal effect of covariates on APA operating costs per dollar of output ${ }^{\dagger}$}

\begin{tabular}{|l|c|}
\hline Homeownership & $+10.6 \%$ \\
\hline Manufacturing & $-8.0 \%$ \\
\hline Income & $+13.5 \%$ \\
\hline Democrats & $+11.6 \%$ \\
\hline Metropolitan area & $+13.1 \%$ \\
\hline
\end{tabular}

† Percentage change in APA intensity is computed for a one standard deviation in the respective variable, from the means of the variables, holding all other covariates constant. The effect of metropolitan area is computed for the discrete change (from being outside to inside an MSA). The marginal effects are based on the regression in column 3 of Table 4.

\section{CONCLUSIONS}

The effect of community characteristics on local environmental outcomes - particularly toxic releases and pollution exposure - has received significant examination in recent years. If it is the case that certain groups face greater exposure to toxic and noxious air, this may be due to an extraordinary number of air polluters locating in such areas (or those groups locate near polluters, perhaps to enjoy lower housing costs) and/or facilities in those areas do not abate as much of their pollution. This paper focuses on the latter by examining whether spending by manufacturing plants on air pollution abatement depends in any way on the characteristics of the surrounding community, including socioeconomic composition, potential political opposition, economic conditions, and 
other possible factors.

This paper's most robust results are from analyses on a subsample of particularly heavy air polluters, which removes establishments that are much less sensitive to the factors under exploration here and/or whose issues may be with solid waste or water pollution rather than air. Having said that, however, the strong effects found with this subsample were also (mostly) found with the full sample as well. In particular, larger per capita income is found to increase APA activity, as is a high degree of homeownership, a concentration of Democratic voters, and being located in an MSA. And among these high polluters, a heavy local presence of manufacturing employment is found to decrease pollution abatement expenditure. Most of these results have precedents in the prior literature, and no "unexpected" effects are found in the preferred model (with full controls) in Table 4. This paper does not attempt to explain whether regulators regulate more [less] stringently in areas with these characteristics or whether the plants themselves simply behave differently in such areas.

As interesting as what is found, is what is not found. First, there is no evidence here that a populace's potential for collective actions (as measured by voter turnout) raises the level of local air pollution abatement expenditure. Only Hamilton $(1993,1995)$ has ever really found this factor to have a positive effect on the local environment. Furthermore, none of the "Coasian" variables seem to have an effect on APA activity, with the exception of per capita income (which has alternative explanations). Finally, support for "environmental injustice" is, at best, mixed. Using the full sample, APA spending is indeed lower in areas with higher nonwhite populations, once the full set of control variables are in place. The percent of the population that is foreign-born, however, had the opposite effect. In terms of the highest air polluters, outlays are larger in nonwhite areas and smaller in counties with many foreign-borns - that is until one controls for state and county-level regulation, which makes even these effects disappear. As this and other examples make clear, controlling for establishment characteristics and regulation is vitally important in a study such as this. 


\section{REFERENCES}

Arora, Seema and Timothy N. Cason. "Do Community Characteristics Influence Environmental Outcomes? Evidence from the Toxic Release Inventory," Southern Economic Journal, 65(4), 691716, April 1999.

Becker, Randy A. "Air Pollution Abatement Costs under the Clean Air Act: Evidence from the PACE Survey," Center for Economic Studies Discussion Paper, 01-12, November 2001. (Revised October 2003.)

Becker, Randy A. and J. Vernon Henderson. "Effects of Air Quality Regulations on Polluting Industries," Journal of Political Economy, 108(2), 379-421, April 2000.

Becker, Randy A. and J. Vernon Henderson. "Costs of Air Quality Regulation," in Behavioral and Distributional Effects of Environmental Policy, Carlo Carraro and Gilbert E. Metcalf (eds.), Chicago: National Bureau of Economic Research and The University of Chicago Press, 2001.

Chay, Kenneth Y. and Michael Greenstone. "Does Air Quality Matter? Evidence from the Housing Market," University of Chicago, Department of Economics, mimeograph, December 2000.

Earnhart, Dietrich. "The Effect of Community Pressure on Polluter Compliance Levels: Is Community Pressure Sufficient for Ensuring Compliance?” University of Kansas, Department of Economics, mimeograph, May 2002.

Gray, Wayne B. and Mary E. Deily. "Compliance and Enforcement: Air Pollution Regulation in the U.S. Steel Industry,” Journal of Environmental Economics and Management, 31(1), 96-111, July 1996.

Gray, Wayne B. and Ronald J. Shadbegian. "“Optimal' Pollution Abatement - Whose Benefits Matter, and How Much?” Journal of Environmental Economics and Management, forthcoming (2004).

Greenstone, Michael. “The Impacts of Environmental Regulations on Industrial Activity: Evidence from the 1970 and 1977 Clean Air Act Amendments and the Census of Manufactures," Journal of Political Economy, 110(6), 1175-1219, December 2002.

Hamilton, James T. "Politics and Social Costs: Estimating the Impact of Collective Action on Hazardous Waste Facilities,” RAND Journal of Economics, 24(1), 101-125, Spring 1993.

Hamilton, James T. “Testing for Environmental Racism: Prejudice, Profits, Political?” Journal of Policy Analysis and Management, 14(1), 107-132, Winter 1995.

Henderson, J. Vernon. "Effects of Air Quality Regulation," American Economic Review, 86(4), 789-813, September 1996.

Hettige, Hemamala, Paul Martin, Manjula Singh, and David Wheeler. "The Industrial Pollution Projection System,” World Bank Policy Research Working Paper, 1431, December 1994.

Kahn, Matthew E. "Particulate Pollution Trends in the United States," Regional Science and Urban Economics, 27(1), 87-107, February 1997. 
Kahn, Matthew E. "The Silver Lining of Rust Belt Manufacturing Decline: Killing Off Pollution Externalities," Center for Economic Studies Discussion Paper, 97-7, June 1997.

Kahn, Matthew E. and John G. Matsusaka. "Demand for Environmental Goods: Evidence from Voting Patterns on California Initiatives," Journal of Law and Economics, 40(1), 137-173, April 1997.

Kriesel, Warren, Terence J. Centner, and Andrew G. Keeler. "Neighborhood Exposure to Toxic Releases: Are There Racial Inequities?" Growth and Change, 27(4), 479-499, Fall 1996.

Levinson, Arik. “An Industry-Adjusted Index of State Environmental Compliance Costs," in Behavioral and Distributional Effects of Environmental Policy, Carlo Carraro and Gilbert E. Metcalf (eds.), Chicago: National Bureau of Economic Research and The University of Chicago Press, 2001.

List, John A. and W. Warren McHone. "Measuring the Effects of Air Quality Regulations on "Dirty" Firm Births: Evidence from the Neo- and Mature-Regulatory Periods," Papers in Regional Science, 79(2), 177-190, April 2000.

StataCorp. Stata Statistical Software: Release 7.0. College Station, TX: Stata Corporation, 2001.

U.S. Bureau of the Census. Pollution Abatement Costs and Expenditures, 19_. Washington, DC: U.S. Government Printing Office, various years.

Wolverton, Ann. "Does Race Matter? An Examination of a Polluting Plant's Location Decision," U.S. Environmental Protection Agency, National Center for Environmental Economics, mimeograph, July 2002. 